(2) Open Access Full Text Article

\title{
Arginine-based cationic liposomes for efficient in vitro plasmid DNA delivery with low cytotoxicity
}

This article was published in the following Dove Press journal:

International Journal of Nanomedicine

9 April 2013

Number of times this article has been viewed

\section{Satya Ranjan Sarker \\ Yumiko Aoshima \\ Ryosuke Hokama \\ Takafumi Inoue \\ Keitaro Sou \\ Shinji Takeoka}

Department of Life Science and Medical Bioscience, Graduate School of Advanced Science and Engineering, Waseda University (TWIns), Tokyo, Japan
Correspondence: Shinji Takeoka Department of Life Science and Medical Bioscience, Graduate School of Advanced Science and Engineering, Waseda University (TWIns), Shinjuku-ku,

Tokyo 162-8480, Japan

Tel +8I 353697324

Fax +8I 353697324

Email takeoka@waseda.jp
Background: Currently available gene delivery vehicles have many limitations such as low gene delivery efficiency and high cytotoxicity. To overcome these drawbacks, we designed and synthesized two cationic lipids comprised of n-tetradecyl alcohol as the hydrophobic moiety, 3-hydrocarbon chain as the spacer, and different counterions (eg, hydrogen chloride [HCl] salt or trifluoroacetic acid [TFA] salt) in the arginine head group.

Methods: Cationic lipids were hydrated in 4-(2-hydroxyethyl)-1-piperazineethanesulfonic acid (HEPES) buffer to prepare cationic liposomes and characterized in terms of their size, zeta potential, phase transition temperature, and morphology. Lipoplexes were then prepared and characterized in terms of their size and zeta potential in the absence or presence of serum. The morphology of the lipoplexes was determined using transmission electron microscopy and atomic force microscopy. The gene delivery efficiency was evaluated in neuronal cells and HeLa cells and compared with that of lysine-based cationic assemblies and Lipofectamine ${ }^{\mathrm{TM}}$ 2000. The cytotoxicity level of the cationic lipids was investigated and compared with that of Lipofectamine 2000.

Results: We synthesized arginine-based cationic lipids having different counterions (ie, HCl-salt or TFA-salt) that formed cationic liposomes of around $100 \mathrm{~nm}$ in size. In the absence of serum, lipoplexes prepared from the arginine-based cationic liposomes and plasmid (p) DNA formed large aggregates and attained a positive zeta potential. However, in the presence of serum, the lipoplexes were smaller in size and negative in zeta potential. The morphology of the lipoplexes was vesicular. Arginine-based cationic liposomes with HCl-salt showed the highest transfection efficiency in PC-12 cells. However, arginine-based cationic liposomes with TFA salt showed the highest transfection efficiency in HeLa cells, regardless of the presence of serum, with very low associated cytotoxicity.

Conclusion: The gene delivery efficiency of amino acid-based cationic assemblies is influenced by the amino acids (ie, arginine or lysine) present as the hydrophilic head group and their associated counterions.

Keywords: cationic liposome, transfection efficiency, cytotoxicity, counterions, pDNA

\section{Introduction}

In 1987, Felgner et al first introduced the concept of the application of cationic liposomes as a gene delivery vehicle. ${ }^{1}$ In vitro delivery of plasmid (p) DNA to various cell lines is the first step towards the treatment of various genetic diseases such as different types of cancer, lysosomal storage disease, congenital blindness, and muscular dystrophy. It can also be equally applied in the treatment of complex neurological disorders. ${ }^{2}$ Since the late twentieth century, researchers have been trying to explore a suitable nonviral vector that could efficiently deliver genetic materials to a variety of cancer cells as 
well as neuronal cells with limited cytotoxicity. However, current methods available for the intracellular pDNA delivery are limited because of the low transfection efficiency and high toxicity. Although viral vectors are highly efficient in delivering genes to the nucleus of a cell, ${ }^{3}$ they have several disadvantages. ${ }^{2,4-8}$ Therefore, successful delivery of genetic materials into various cell lines with high efficiency and low cytotoxicity would be a step toward the treatment of several complex genetic disorders as well as toward exploring the function and dynamics of different functional proteins.

Nonviral vectors are an attractive alternative to viruses since they are less toxic than viruses, cost effective, and can be targeted to specific neuronal subpopulations. ${ }^{2}$ Until now, several nonviral gene delivery vectors have been investigated into various cancer and neuronal cells. ${ }^{4,9-20}$ Physical methods (eg, electroporation) have also been used to deliver nucleic acids to cultured neurons. ${ }^{21,22}$ However, in the case of electroporation, the application of electric field in close proximity to cells and the lack of cell type specificity are limitations. ${ }^{2}$

Cationic lipids are comprised of a hydrophilic head group and a hydrophobic moiety such as hydrocarbon chains ${ }^{23,24}$ or a cholesterol derivative. ${ }^{25-27}$ The gene delivery efficiency of the cationic assemblies is influenced by the length ${ }^{28}$ and saturation level ${ }^{29}$ of the hydrophobic alkyl chain, type of amino acid in the cationic head group, ${ }^{30}$ and the characteristics of the linker. ${ }^{31-33}$ Furthermore, a suitable spacer, in terms of length and nature, influences the gene delivery efficiency and serum compatibility of cationic liposomes. ${ }^{34-37}$ Recently, we reported that the ionization states of the cationic head group influence the phase transition temperature, morphology, and transfection efficiency of the lysine-based cationic assemblies. ${ }^{38}$ More specifically, lysine-based cationic assemblies with trifluoroacetic acid (TFA) salt as the counterion and a 3-hydrocarbon chain spacer between the lysine head group and the hydrophobic moiety showed the highest transfection efficiency in COS-7 cells. ${ }^{38}$

In the study reported here, we synthesized argininebased cationic lipids with different counterions (ie, $\mathrm{HCl}$ salt or TFA-salt) in the arginine head group, while keeping the length of hydrocarbon chain spacer and hydrophobic moiety fixed to three and 14 carbons, respectively. Cationic liposomes were prepared from the only synthetic cationic lipids through a simple hydration method and no helper lipids, such as dioleoylphosphatidylcholine (DOPE), dipalmitoylphosphatidylcholine (DPPC), or cholesterol, were introduced. The liposomes were then characterized with regard to their size, zeta potential, phase transition temperature, and morphology. Following this, lipoplexes were prepared from the cationic liposomes and pDNA and characterized in terms of their size, zeta potential, and morphology. The transfection efficiency and the cytotoxicity of the arginine-based cationic liposomes were evaluated using transplantable rat pheochromocytoma cells, PC-12, a neuronal cell line, and human cervical cancer cells, HeLa. The transfection efficiency was compared with that of the lysinebased cationic assemblies and Lipofectamine ${ }^{\text {TM }} 2000$ and the cytotoxicity was compared with that of Lipofectamine ${ }^{\mathrm{TM}} 2000$.

\section{Materials and methods Materials}

L-Glutamic acid, $p$-toluene sulfonic acid monohydrate ( $p$-Tos), benzotriazol-1-yloxytris (dimethylamino) phosphonium hexafluorophosphate (BOP), and tetradecyl alcohol were purchased from the Kanto Chemical Co (Tokyo, Japan). 4-Aminobutyric acid was purchased from the Tokyo Chemical Industry Co (Tokyo, Japan). $N_{\alpha}, N_{\delta}, N_{\omega}$-tritert-butoxycarbonyl-L-arginine [Boc- $\left.\mathrm{Arg}(\mathrm{Boc})_{2}-\mathrm{OH}\right]$ and di-tert-butyl dicarbonate were purchased from the Kokusan Chemical Co (Tokyo, Japan). All the organic solvents used in the synthesis of arginine-based cationic lipids were purchased from the Kanto Chemical Co.

\section{Syntheses}

\section{Syntheses of cationic lipids}

We synthesized arginine-based cationic lipids with $\mathrm{HCl}$-salt (cationic lipid a) and TFA-salt (cationic lipid b) according to the previously optimized protocol ${ }^{38}$ as shown in Figure 1 (explained in the "Supplementary information" section). Deprotection with $\mathrm{HCl}$ (4 M) in ethyl acetate, followed by the removal of excess $\mathrm{HCl}$ under reduced pressure gave cationic lipid a. Deprotection with TFA at $4{ }^{\circ} \mathrm{C}$ overnight followed by the removal of excess TFA under reduced pressure gave cationic lipid $\mathbf{b}$. The synthesis of lysine-based cationic lipids (ie, $\mathbf{c}$ and $\mathbf{d}$ ) has already been described in our previous report. ${ }^{38}$

\section{Preparation of cationic assemblies}

All the synthetic lipids (ie, cationic lipids a-d) (10 mg) were hydrated in $1 \mathrm{~mL}$ 4-(2-hydroxyethyl)-1piperazineethanesulfonic acid (HEPES) buffer $(20 \mathrm{mM}$, $\mathrm{pH}$ 7.4) for 12-16 hours upon gentle stirring to prepare the respective cationic assemblies.

\section{Formation of cationic assembly-pDNA complexes}

To form the lipoplexes, pDNA encoding Renilla luciferase (0.2 $\mu \mathrm{g}$, pGL4.75[hRluc/CMV]; Promega, Madision, WI, USA) 




1,5-DitetradecylL-glutamate
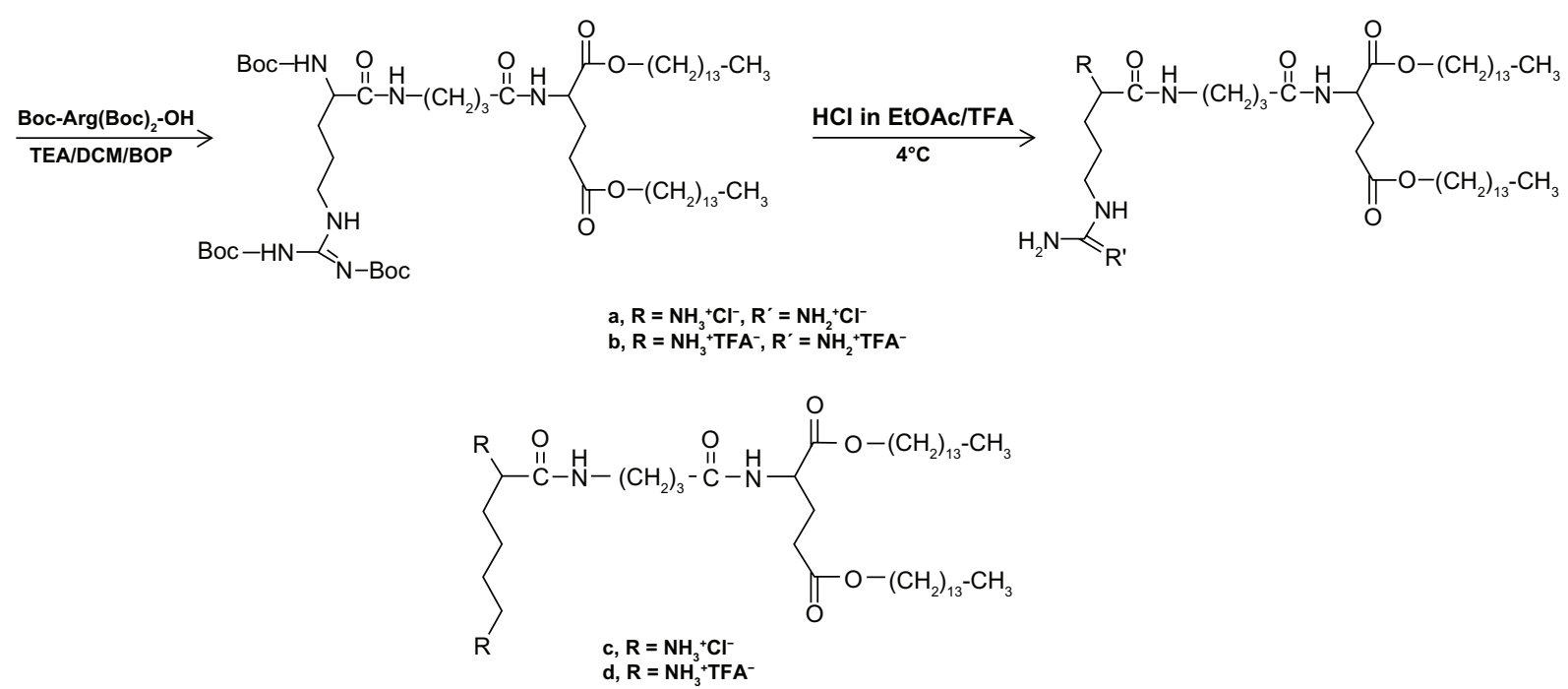

Figure I Syntheses of arginine-based cationic lipids.

Abbreviations: BOP, benzotriazol-I-yloxytris (dimethylamino) phosphonium hexafluorophosphate; EtOAc, ethyl acetate; DCM, dichloromethane; HCl, hydrogen chloride; TEA, triethylamine; TFA, trifluoroacetic acid.

was added to the dispersion of the cationic assemblies (0.6-6.0 $\mu \mathrm{g}$ lipid), mixed gently, then incubated at room temperature for 15-20 minutes. The lipoplex solutions were then diluted with Dulbecco's modified Eagle's medium (DMEM) or DMEM/F12 with or without serums (ie, fetal bovine serum [FBS] and horse serum [HS]) to analyze the gene transfer efficiency. Lipofectamine ${ }^{\mathrm{TM}} 2000$ (Invitrogen, Carlsbad, CA, USA) was used as the positive control for gene transfer studies.

\section{Determination of the morphology of liposomes and lipoplexes}

The arginine-based cationic liposomes were observed by transmission electron microscopy (TEM) and atomic force microscopy (AFM). For TEM observation, the cationic lipid dispersion $(5 \mu \mathrm{L})$ was mixed with $1 \%(5 \mu \mathrm{L})$ phosphotungstic acid ( $\mathrm{pH} 7.4$ ) and incubated for 3 minutes. Then a drop of the liposomes was put on a 150 mesh copper grid and the excess dispersion was cleansed carefully with a Whatman ${ }^{\circledR}$ number 1 filter paper (Maidstone, UK) and kept in a desiccator for around 12 hours. Finally, the morphology of the cationic liposomes was observed under a transmission electron microscope (JEM-1230, JEOL, Tokyo, Japan). For AFM observation, $15 \mu \mathrm{L}$ of the liposome solution was put into a Whatman
Cyclopore $^{\circledR}$ filter, which is a polyester membrane (size: $0.2 \mu \mathrm{m}$ ); washed twice with deionized water; and aspirated to remove the residual water. Finally, the filter was placed in a filter holder and dried in a desiccator for 3 hours before being observed under an atomic force microscope (Nano Scale Hybrid Microscope VN-8010, Keyence, Osaka, Japan).

The morphology of the lipoplexes was determined using TEM and AFM. Briefly, to prepare the lipoplex sample, arginine-based cationic liposomes and pDNA were mixed at $10 / 1(\mathrm{w} / \mathrm{w})$ ratio and incubated at room temperature for 20 minutes before being diluted with $20 \mathrm{mM}$ HEPES buffer (pH 7.4). For TEM observation, the diluted solution was then mixed with equal volume of $1 \%$ phosphotungstic acid (pH 7.4) and observed in the same way as the liposomes. In the case of AFM observation, $15 \mu \mathrm{L}$ of the lipoplex solution $(0.2 \mu \mathrm{g}$ pDNA and $2 \mu \mathrm{g}$ lipid) was put into a Cyclopore filter (size: $0.2 \mu \mathrm{m}$ ), washed twice with deionized water, and aspirated to remove the residual water before being observed using an AFM in the same way as the liposomes.

\section{Zeta potential and size measurements}

The hydrodynamic diameter of the arginine-based cationic liposomes and lipoplexes was measured with a dynamic light 
scattering spectrophotometer (Zetasizer Nano-ZS, Malvern Instruments, Malvern, UK) equipped with a 633-nm laser module with a detector at 173 degrees. We used Nanosphere Size Standards (60 nm; Thermo Fisher Scientific, Waltham, MA, USA) for the performance verification of the measurement. The mean size was determined based on the intensity results. The sizes of the cationic liposomes a and $\mathbf{b}(5 \mu \mathrm{L}$, concentration: $10 \mathrm{mg} / \mathrm{mL}$ lipid $)$ were measured in $20 \mathrm{mM}$ HEPES buffer (1 mL, pH 7.4). The sizes of the lipoplexes $(0.6-6.0 \mu \mathrm{g}$ lipid and $0.2 \mu \mathrm{g}$ pDNA) were measured in DMEM without serum and DMEM with $10 \%$ FBS. The zeta potentials of cationic liposomes $\mathbf{a}$ and $\mathbf{b}$ and lipoplexes were measured with the Zetasizer Nano-ZS. The cationic liposomes $(0.1 \mathrm{mg} / \mathrm{mL}$ lipid $)$ in $20 \mathrm{mM}$ HEPES buffer ( $\mathrm{pH}$ 7.4) and the lipoplexes (0.6-6.0 $\mu \mathrm{g}$ lipid and $0.2 \mu \mathrm{g}$ pDNA) in DMEM without serum and DMEM with $10 \%$ FBS were put into a capillary cell then mounted on the apparatus and measured five times at $37^{\circ} \mathrm{C}$.

\section{Differential scanning calorimetry (DSC)}

DSC was used to determine the phase transition temperature of cationic liposomes a and $\mathbf{b}$. The cationic liposome samples $(20 \mu \mathrm{L}, 200 \mu \mathrm{g})$ were added to an aluminum crucible, sealed in, and this was used as a sample holder. The scan rates were $2^{\circ} \mathrm{C} / \mathrm{min}$ starting from $0^{\circ} \mathrm{C}$ and going up to $80^{\circ} \mathrm{C}$ and performed for three cycles. The phase transition temperature was calculated from the thermograms obtained between $0^{\circ} \mathrm{C}$ and $80^{\circ} \mathrm{C}$ and thermograms were referenced against $20 \mathrm{mM}$ HEPES buffer ( $\mathrm{pH}$ 7.4).

\section{Cationic liposome-pDNA binding assay by agarose gel electrophoresis}

The pDNA binding ability of cationic liposomes a and $\mathbf{b}$ was investigated by loading the lipoplexes onto a $1 \%$ agarose gel (Takara Bio, Otsu, Japan) pre-stained with ethidium bromide. The lipoplexes were prepared by mixing $5 \mu \mathrm{L}$ of pDNA $(0.2 \mu \mathrm{g})$ with $10 \mu \mathrm{L}$ of liposomes containing various amounts of cationic lipids $(0.6-6.0 \mu \mathrm{g})$ and incubated for 15-20 minutes at room temperature. The lipoplex solutions were then diluted with either only DMEM or DMEM containing $10 \%$ FBS and the volume adjusted to $100 \mu \mathrm{L}$. Finally, $20 \mu \mathrm{L}$ aliquots of the respective lipoplex solutions were mixed with $6 \times$ gel-loading buffer ( $4 \mu \mathrm{L}$; Invitrogen). The samples $(20 \mu \mathrm{L})$ were then loaded on the previously cast gel and electrophoresed at $100 \mathrm{~V}$ for 30 minutes before being visualized using a UV Transilluminator gel documentation unit with BioDoc-It ${ }^{\circledR}$ Imaging System (UVP, Upland, CA, USA).

\section{Cell cultures}

PC-12 cells (transplantable rat pheochromocytoma cells) and HeLa cells were cultured in DMEM supplemented with $10 \% \mathrm{HS}, 10 \% \mathrm{FBS}, 100 \mathrm{IU} / \mathrm{mL}$ penicillin, and $100 \mu \mathrm{g} / \mathrm{mL}$ streptomycin. Both cell cultures were maintained in an atmosphere of $5 \% \mathrm{CO}_{2}$ at $37^{\circ} \mathrm{C}$.

\section{Transfection biology}

The gene delivery efficiencies of the lipoplexes were investigated in the cultured PC-12 and HeLa cells. The PC-12 and HeLa cells were plated at a density of $2.5 \times 10^{4}$ and $1 \times 10^{4}$ cells/well, respectively, into a 96 -well plate and incubated in an atmosphere of $5 \% \mathrm{CO}_{2}$ at $37^{\circ} \mathrm{C}$ overnight. The medium was then replaced with the lipoplexes $(100 \mu \mathrm{L})$ containing various amounts of the cationic lipids $(0.6-6.0 \mu \mathrm{g})$ and $0.2 \mu \mathrm{g}$ of pDNA ( $3 / 1$ to $30 / 1 \mathrm{w} / \mathrm{w}$ or 1.28 to $12.8 \mathrm{~N} / \mathrm{P}$ ratio). In the case of the PC-12 cells, $100 \mu \mathrm{L}$ complete DMEM was added to each well 2 hours after transfection in the absence of serum. The old medium was then replaced with complete DMEM 24 hours after transfection both in the absence and in the presence of serum (10\% FBS and $10 \%$ HS for PC- 12 cells and only 10\% FBS for HeLa cells). After 48 and 72 hours of transfection of the PC-12 and HeLa cells, respectively, the old DMEM was aspirated and the cells were washed with ice-cold phosphate-buffered saline. The cells were then lysed with a lysis buffer provided with a Renilla Luciferase Assay System (Promega, Madison, WI, USA). The luciferase assay kit was used to measure the luciferase activity of the cell lysate $(10 \mu \mathrm{L})$ with a GLOMAX ${ }^{\mathrm{TM}}$ Microplate Luminometer (Promega). The total protein concentration of the cell lysate was determined using a Bio-Rad Quick Start ${ }^{\mathrm{TM}}$ protein assay kit (Hercules, CA, USA) and this was used to normalize the luciferase activity in each sample. The luciferase activity was expressed as a relative light unit (RLU) per milligram of protein. The data represent the average gene expression efficiency of five samples $(n=5)$ performed in triplicate on three different days. Lipofectamine ${ }^{\mathrm{TM}} 2000$ (1 $\mu \mathrm{g}$; Invitrogen) was used as the positive control for gene-transfer studies.

\section{Cytotoxicity assay}

The cytotoxicity of cationic liposomes a and $\mathbf{b}$ was investigated in PC-12 and HeLa cells by water-soluble tetrazolium-1 (WST-1) assay. The cytotoxicity assays were performed in 96-well plates by maintaining the same number of cells as used in the transfection experiments. The PC-12 and HeLa cell culture medium was exchanged with complete DMEM (10\% HS and 10\% FBS) and complete DMEM (10\% FBS), respectively, containing various concentrations of liposomes 
$(5-400 \mu \mathrm{g} / \mathrm{mL})$ and Lipofectamine ${ }^{\mathrm{TM}} 2000(5-100 \mu \mathrm{g} / \mathrm{mL})$, whereas the lipid concentrations used in the transfection assay were $6-60 \mu \mathrm{g} / \mathrm{mL}$. Both cell lines were then incubated, the PC-12 cells for 48 and the HeLa cells for 72 hours, in an atmosphere of $5 \% \mathrm{CO}_{2}$ at $37^{\circ} \mathrm{C}$. Finally, the old medium was replaced with tetrazolium salt (WST-1) containing complete $\operatorname{DMEM}(110 \mu \mathrm{L})$ and incubated for 1 hour. The absorbance was then measured at $440 \mathrm{~nm}$ using a microplate reader (PerkinElmer Japan, Tokyo, Japan).

\section{Results}

\section{Syntheses of arginine-based cationic lipids}

We synthesized two arginine-based cationic lipids, $\mathbf{a}$ and $\mathbf{b}$, with different counterions (ie, $\mathrm{HCl}$-salt and TFAsalt, respectively) and a 3-hydrocarbon chain spacer between the arginine head group and the hydrophobic moiety. Both cationic lipids comprised 1,5-ditetradecyl-L-glutamate as a hydrophobic moiety. To introduce the 3-hydrocarbon chain spacer, 4-aminobutyric acid was conjugated with 1,5-ditetradecyl-L-glutamate via an amide linkage, as shown in Figure 1. Then, a protected arginine moiety was introduced as the cationic head group. Cationic lipids $\mathbf{a}$ and $\mathbf{b}$ were obtained by deprotection with $\mathrm{HCl}$ (4 M) in ethyl acetate and TFA, respectively, followed by the removal of the respective acids under reduced pressure. Both the cationic lipids, including intermediates as shown in Figure 1, were characterized by proton nuclear magnetic resonance ( $\left.{ }^{1} \mathrm{H}-\mathrm{NMR}\right)$, carbon-13 nuclear magnetic resonance $\left({ }^{13} \mathrm{C}-\mathrm{NMR}\right)$, and electrospray ionization mass spectrometry (ESI-MS) (see "Supplementary information"). The lysine-based cationic lipids $\mathbf{c}$ and $\mathbf{d}$, with different counterions, that is, HCl-salt and TFA-salt, respectively, in the lysine head group and a 3-hydrocarbon chain spacer between the head group and the hydrophobic moiety, were synthesized and characterized as reported in our previous study. ${ }^{38}$

\section{Structure and physicochemical properties of the cationic liposomes}

The counterions present in the arginine head group influenced the hydrodynamic size and zeta potential of the cationic liposomes $\mathbf{a}$ and $\mathbf{b}$ (Table 1). The average hydrodynamic diameter of liposomes $\mathbf{a}$ and $\mathbf{b}$ was $80 \pm 39$ and $103 \pm 50 \mathrm{~nm}$, respectively. The data were the mean average size \pm standard deviation of three independent measurements. In addition, the polydispersity index of liposomes $\mathbf{a}$ and $\mathbf{b}$ were 0.261 and 0.231 , respectively, with a unimodal curve. The zeta potential of $\mathbf{b}(\mathrm{ie},+45 \mathrm{mV}$ ) was higher due to the presence of TFA salt counterion. ${ }^{38}$ The TEM images show that both
Table I Apparent hydrodynamic diameter, zeta potential, and phase transition temperature of each of the arginine-based cationic liposomes

\begin{tabular}{lcll}
\hline Liposome & $\begin{array}{l}\text { Hydrodynamic } \\
\text { diameter }(\mathrm{nm})\end{array}$ & $\begin{array}{l}\text { Zeta potential } \\
(\mathrm{mV})\end{array}$ & $T_{c}\left({ }^{\circ} \mathbf{C}\right)$ \\
\hline a & $80 \pm 39$ & $35 \pm 4$ & 23.0 \\
b & $103 \pm 50$ & $45 \pm 3$ & 24.5 \\
c & $20 \pm 9$ & $41 \pm 6$ & - \\
d & $91 \pm 41$ & $60 \pm 6$ & 24.5 \\
\hline
\end{tabular}

The physicochemical properties of $\mathrm{c}$ and $\mathrm{d}$ have been taken from Sarker et al. ${ }^{38}$ Abbreviation: $T_{c}$, phase transition temperature.

the cationic liposomes had a vesicular structure (Figure 2A and $\mathrm{B}$ ). In contrast, the AFM images show a heterogeneous morphology for liposomes $\mathbf{a}$ and $\mathbf{b}$ (Figure $2 \mathrm{C}$ and $\mathrm{D}$ ).

\section{Thermotropic phase behavior of arginine- based cationic liposomes}

The thermograms obtained from DSC showed that the phase transition temperature of cationic liposomes $\mathbf{a}$ and $\mathbf{b}$ were $23.0^{\circ} \mathrm{C}$ and $24.5^{\circ} \mathrm{C}$, respectively (Table 1 ). Therefore, the counterions had no significant influence on the phase transition temperature of $\mathbf{a}$ and $\mathbf{b}$.

\section{Morphology and physicochemical properties of the lipoplexes}

Both TEM and AFM images of the lipoplexes show a heterogeneous morphology (Figure 3A-D) including coalesced solid spheres. However, some aggregates of the $a / p D N A$ and $\mathbf{b} / \mathrm{pDNA}$ complexes were formed due to fusion of the spherical lipoplexes. The sizes of the complexes obtained from TEM and AFM images were roughly consistent with those obtained through dynamic light scattering (Figure 4). The exact hydrodynamic diameter (ie, size) of the complexes could not be expected to be determined from TEM and AFM images because the samples were kept in a vacuum for 12 and 3 hours before TEM and AFM observation, respectively. This in vacuo condition results in the dehydration of the complexes, which ultimately affects their size. There was no difference in the morphology of the lipoplexes prepared from cationic lipids a and $\mathbf{b}$ and they were heterogeneous vesicular structures.

The lipoplexes prepared from $\mathbf{a}$ and $\mathbf{b}$ were characterized in terms of their size and zeta potential in the absence and in the presence of serum. In the absence of serum, the size of the lipoplexes increased with the increasing ratio of lipid-to-pDNA from 3/1 to $10 / 1$ (w/w) (ie, 1.28 to $12.8 \mathrm{~N} / \mathrm{P}$ ) (Figure 4A and C). However, any further increase in the ratio resulted in a gradual decrease in the size of 

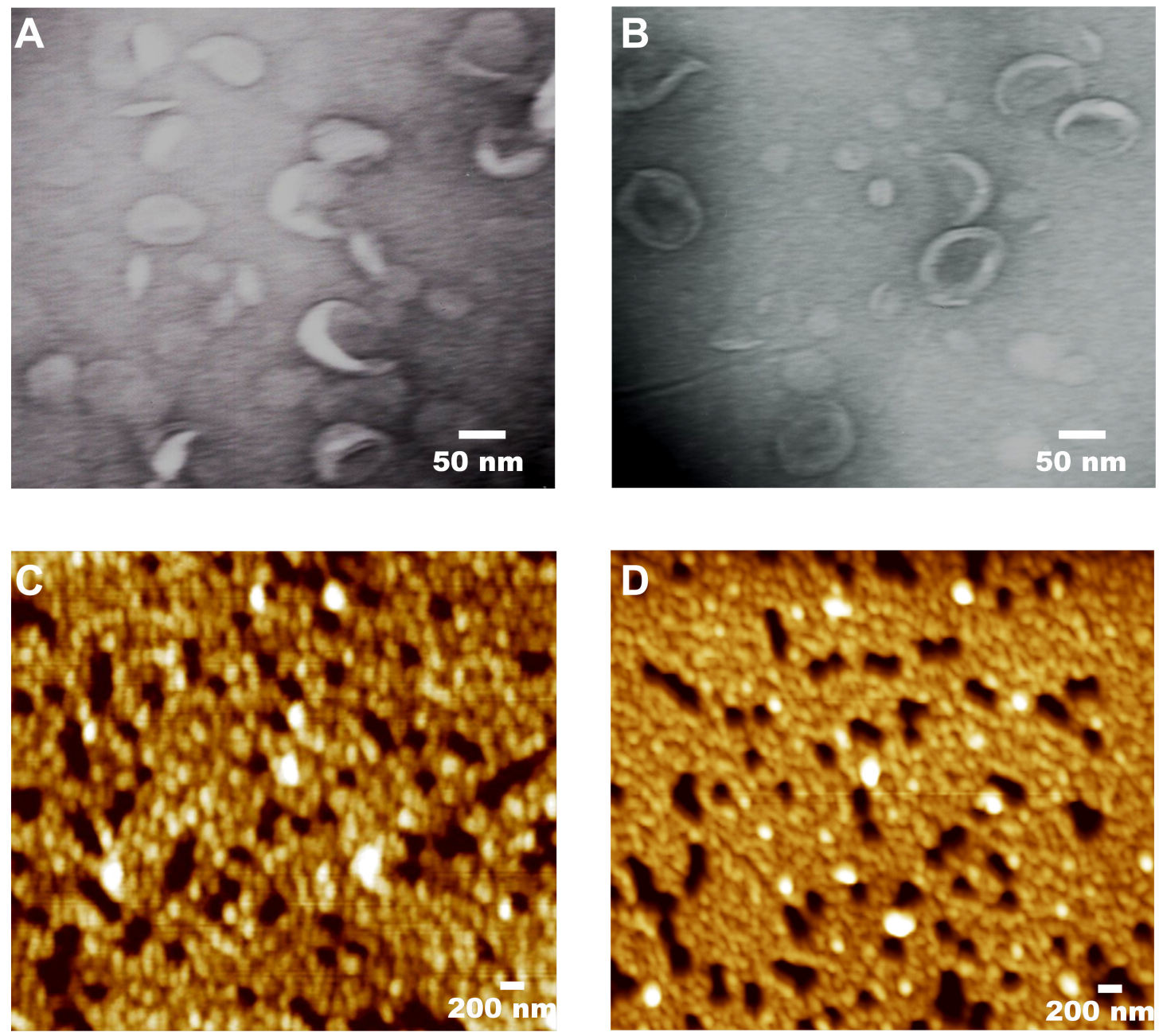

Figure 2 Transmission electron microscope images of the arginine-based cationic liposomes constructed with (A) a and (B) b. The cationic liposomes were stained with I\% phosphotungstic acid. Atomic force microscope images of the liposomes constructed with (C) $\mathbf{a}$ and (D) $\mathbf{b}$.

the lipoplexes. In contrast, in the presence of serum, the size of the lipoplexes increased with the increasing ratio from $3 / 1$ to $5 / 1$, followed by a sharp decrease in the size of the lipoplexes as the ratio increased further (Figure 4B and D).

In the absence of serum, the zeta potential of the lipoplexes remained almost the same (ie, around $-28 \mathrm{mV}$ ) as the lipid-to-pDNA ratio increased from $3 / 1$ to $5 / 1(\mathrm{w} / \mathrm{w})$ followed by a sharp increase in the zeta potential as the ratio increased from $5 / 1$ to $10 / 1$ (ie, $+14 \mathrm{mV}$ at $10 / 1$; Figure $4 \mathrm{~A}$ and C). A further increase in the ratio from $10 / 1$ to $30 / 1$ resulted in a gradual rise of the zeta potential up to $+30 \mathrm{mV}$ for $\mathbf{a} / \mathrm{pDNA}$ and $+24 \mathrm{mV}$ for $\mathbf{b} / \mathrm{pDNA}$. However, in the presence of serum, there was a gradual rise in the zeta potential of the lipoplexes (ie, from around $-17 \mathrm{mV}$ to $-10 \mathrm{mV}$ ) when the ratio increased from $3 / 1$ to $10 / 1$ (Figure $4 \mathrm{~B}$ and $\mathrm{D}$ ). A further increase in the ratio from $15 / 1$ to $30 / 1$ resulted in almost the same zeta potential (ie, $-10 \mathrm{mV}$ ).

\section{Cationic liposome-pDNA binding assay}

The cationic liposome-pDNA binding assay at various cationic lipid-to-pDNA charge ratios was studied by agarose gel electrophoresis. The lipoplexes were prepared and diluted with either DMEM without FBS or DMEM containing $10 \%$ FBS. For lipid a, there were faint bands of pDNA at ratios $3 / 1$ to $10 / 1(\mathrm{w} / \mathrm{w})$ in the absence of serum. However, there was no such band in the presence of serum (Figure 5A). For lipid b, there was a faint band of pDNA at ratio $3 / 1$ in the absence of serum and no band visible in the presence of serum at any lipid-to-pDNA ratios (Figure 5B). In the presence of serum, there was a smear band for only pDNA because of its interaction with the serum proteins. DMEM constituents (ie, ions, amino acids, and vitamins) could also influence the migration of pDNA in the absence of serum. Furthermore, when only pDNA without DMEM and FBS was loaded onto the gel, multiple bands were visible because of the different topologies of the plasmid vectors. 

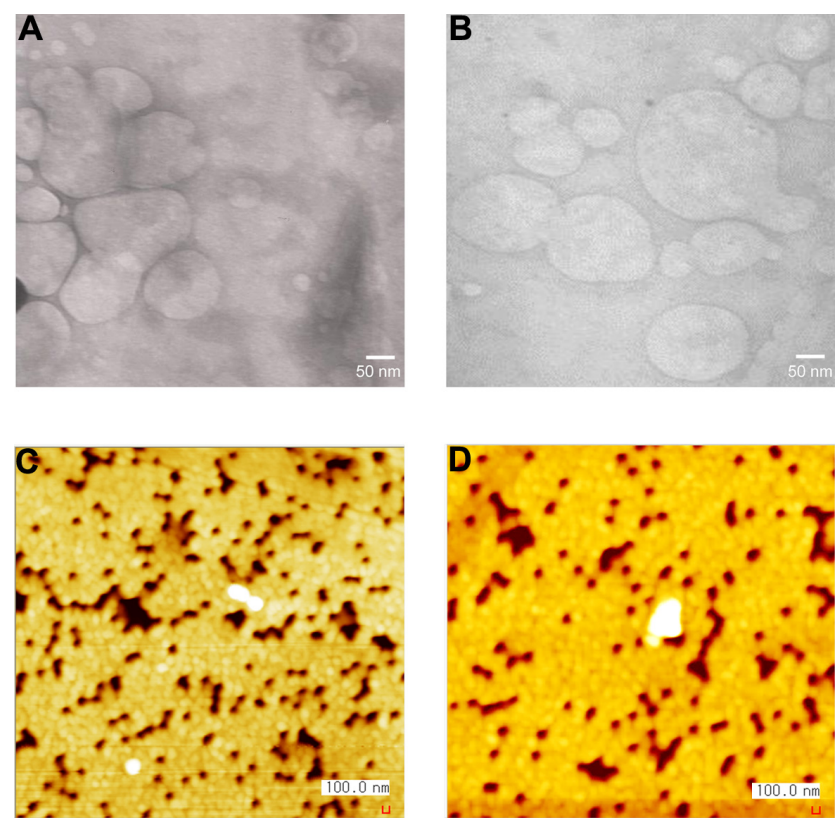

Figure 3 Morphology of the lipoplexes prepared at 10/I (w/w) lipid-to-plasmid (p) DNA ratio. Transmission electron microscope images of $a / p D N A(A)$ and b/pDNA (B); atomic force microscope images of a/pDNA (C) and b/pDNA (D).

\section{In vitro gene delivery efficiency of the cationic assemblies}

Luciferase gene $(l u c)$ expression assay was used for evaluating the in vitro gene delivery efficiency of cationic assemblies a-d in PC-12 and HeLa cells (Figure 6A-D).

\section{A}

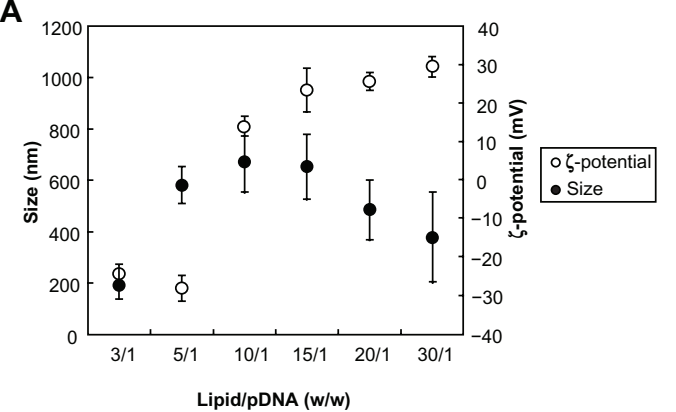

C

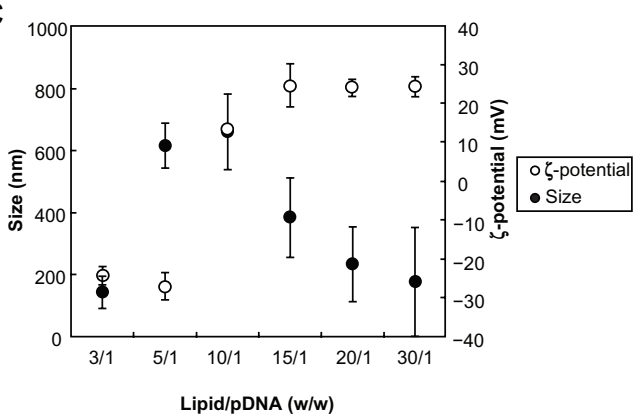

The gene delivery efficiency was performed both in the absence and in the presence of serum (10\% FBS) using lipoplexes prepared by varying lipid-to-pDNA charge ratios (ie, $3 / 1$ to $30 / 1 \mathrm{w} / \mathrm{w}$ or 1.28 to $12.8 \mathrm{~N} / \mathrm{P}$ ) in which the concentration of pDNA was kept constant at $2 \mu \mathrm{g} / \mathrm{mL}$. In the PC-12 cell line, a showed the highest transfection efficiency followed by $\mathbf{b}$, regardless of the presence of serum. The highest efficiency was observed at the ratio of $15 / 1(\mathrm{w} / \mathrm{w})$ (ie, $6.4 \mathrm{~N} / \mathrm{P}$ ), which was around 4 - and 4.5 -fold greater than that of Lipofectamine ${ }^{\mathrm{TM}} 2000$ in the absence and presence of serum, respectively. However, the transfection efficiency of $\mathbf{c}$ and $\mathbf{d}$ in the PC-12 cell line was very low.

In HeLa cells, the highest transfection efficiency was obtained for $\mathbf{b}$ at $10 / 1(\mathrm{w} / \mathrm{w})(\mathrm{ie}, 4.26 \mathrm{~N} / \mathrm{P})$ ratio, which was 1.5- and 1.8- fold greater than that of Lipofectamine ${ }^{\mathrm{TM}}$ 2000 in the absence and in the presence of serum, respectively. Interestingly, the efficiency of $\mathbf{d}$ in HeLa cells was also higher than that of Lipofectamine ${ }^{\mathrm{TM}} 2000$ at 10/1 (w/w) both in the absence and presence of serum.

\section{Cytotoxicity}

The cytotoxicity of the arginine-based cationic liposomes (ie, $\mathbf{a}$ and $\mathbf{b}$ ) was also investigated in PC-12 and HeLa cells (Figure 7A and B). The percentage of viable cells was higher at all cationic lipid concentrations than that of Lipofectamine ${ }^{\mathrm{TM}}$ 2000. More specifically, more than $50 \%$ cells were viable in

\section{B}
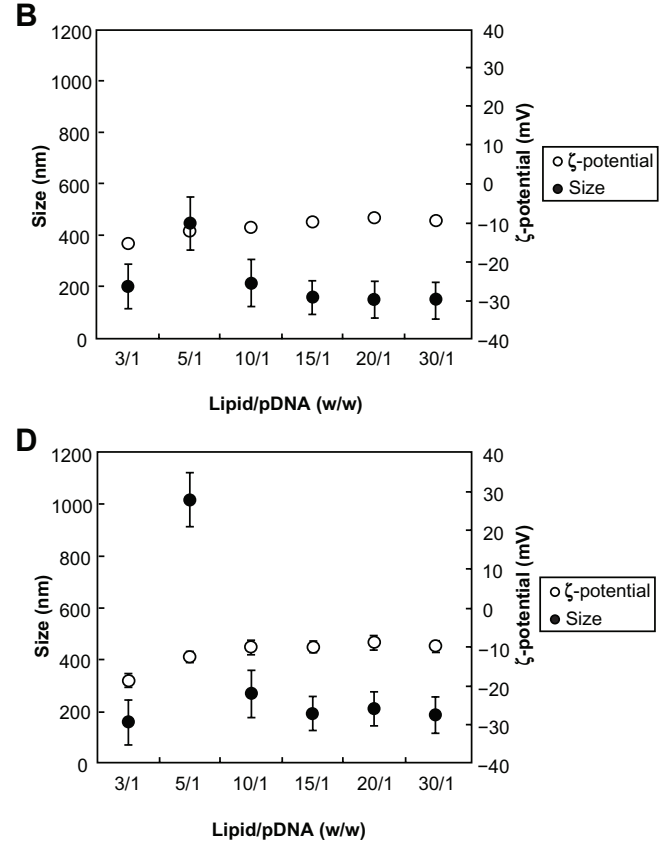

Figure 4 Size and zeta potential of the lipoplexes prepared from the arginine-based cationic liposomes and plasmid ( $P$ ) DNA at a varying lipid-to-pDNA ratios (w/w). Lipoplexes were prepared and diluted with Dulbecco's modified Eagle's medium in the absence $(\mathbf{A}) \mathbf{a}$ and $(\mathbf{C}) \mathbf{b}$ and in the presence of serum $(\mathbf{B}) \mathbf{a}$ and $(\mathbf{D}) \mathbf{b}$.

Notes: The differences in size and zeta potential of the lipoplexes observed in the presence and in the absence of serum were statistically significant $(P<0.0 \mathrm{I})$. Data are presented as the mean \pm standard deviation $(n=5)$. 


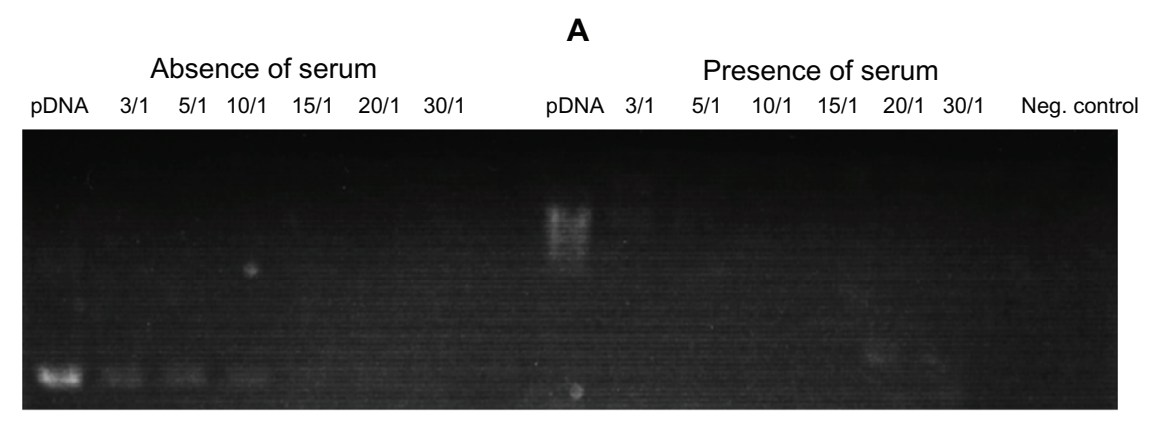

B

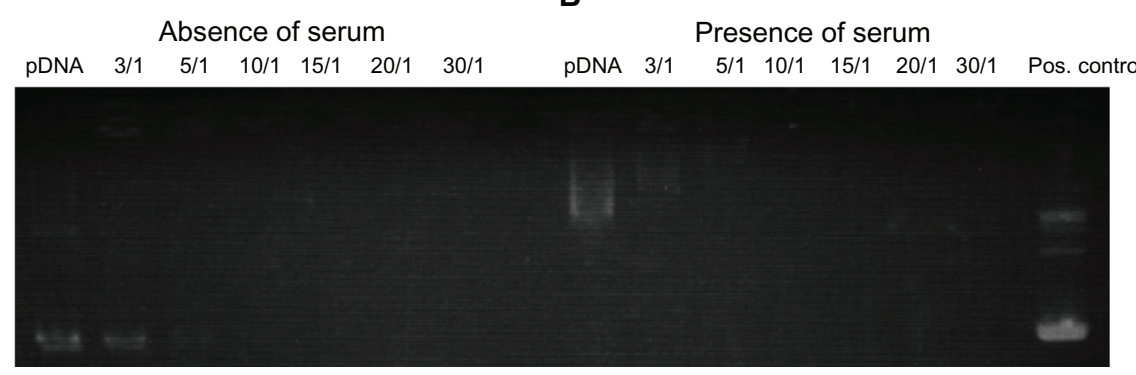

Figure $5 \mathrm{Gel}$ retardation assay of the lipoplexes prepared at different lipid (0.6-6.0 $\mu \mathrm{g})$ to plasmid (p) DNA (0.2 $\mu \mathrm{g})$ ratios (ie, $3 / \mathrm{I}$ to $30 / \mathrm{I}$ w/w or I.28 to I2.8 N/P ratios) in the absence and presence of serum, $(\mathbf{A}) \mathbf{a}$ and $(\mathbf{B}) \mathbf{b}$.

Notes: "Neg. control" (the right-most well of A) denotes that Dulbecco's modified Eagle's medium (DMEM) with $10 \%$ fetal bovine serum (FBS) was loaded. "Pos. control" (the right-most well of $\mathbf{B}$ ) denotes that $0.2 \mu \mathrm{g}$ plasmid DNA without DMEM and FBS was loaded.

A

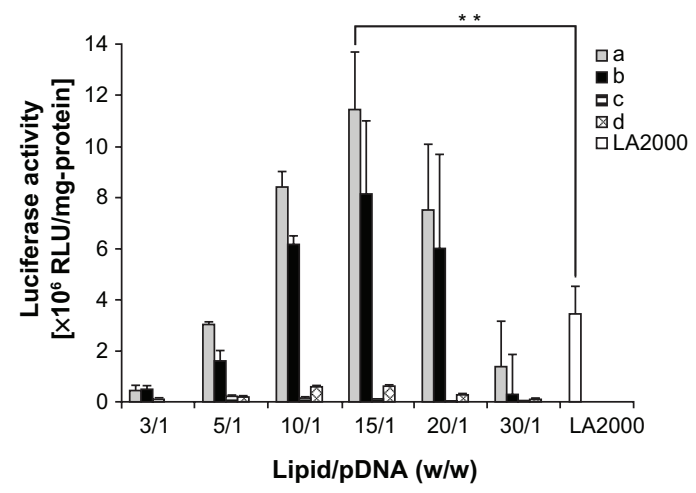

C

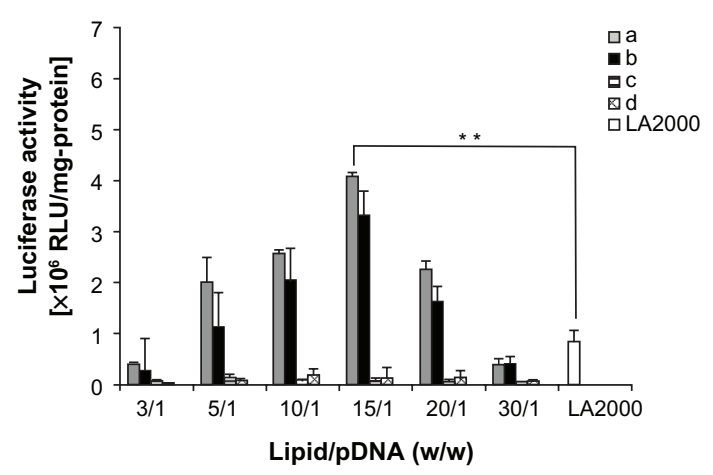

B

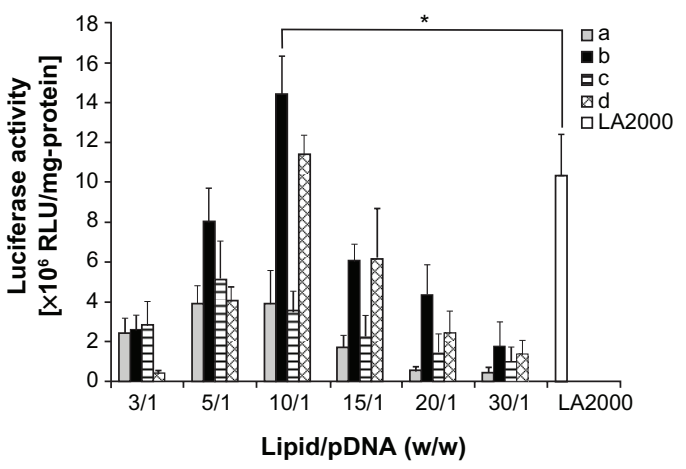

D

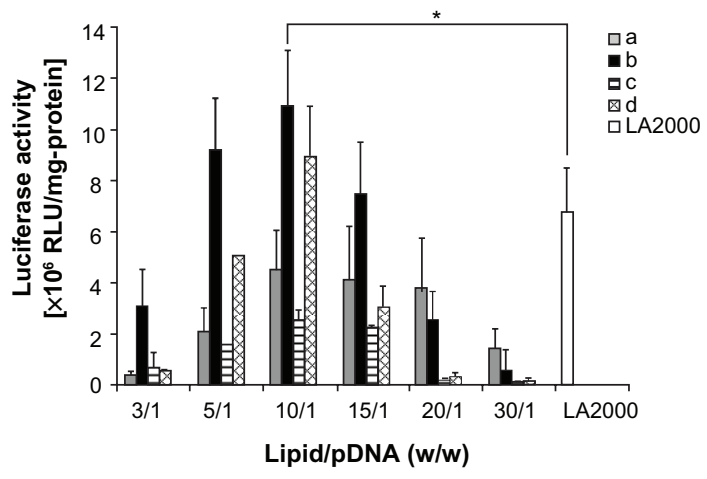

Figure 6 The transfection efficiency of each of the amino acid-based cationic assemblies, (a-d), was compared with that of Lipofectamine ${ }^{\text {TM }} 2000$ (LA2000) in PC-I2 and HeLa cells. Transfection experiments were performed in the absence of serum in PC-12 cells (A) and HeLa cells (B) and in the presence of serum in PC-12 cells (C) and HeLa cells (D). Notes: Units of luciferase activity are plotted against the various lipid-to-plasmid $(\mathrm{p})$ DNA ratios $(\mathrm{w} / \mathrm{w})$. Data are presented as the mean \pm standard deviation $(\mathrm{n}=5)$; $* P<0.05$; ** $P<0.01$.

Abbreviation: RLU, relative light unit. 
A

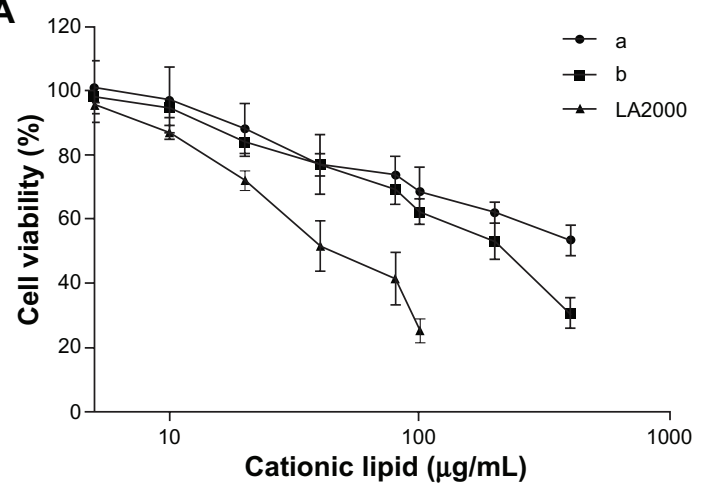

B

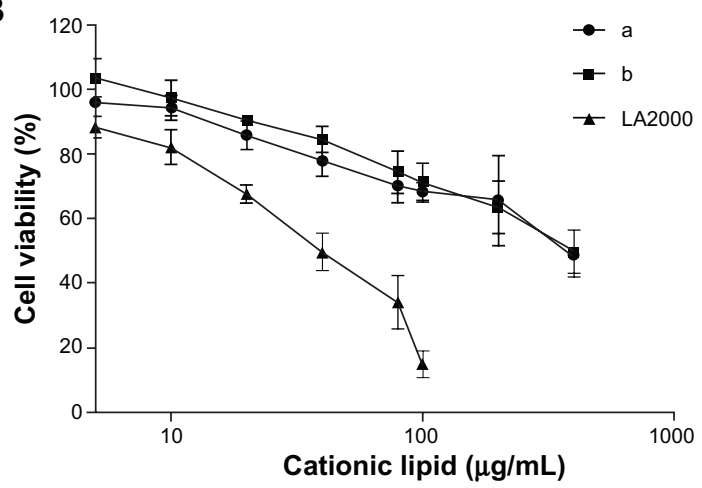

Figure 7 Cytotoxicity of the arginine-based cationic liposomes was compared with that of Lipofectamine 2000 (LA2000) in PC-12 cells (A) and HeLa cells (B). Notes: Cytotoxicity experiment was performed in the presence of serum (I0\% fetal bovine serum) and estimated through water-soluble tetrazolium-I assay. Data were analyzed and are presented plotted in a semi-logarithmic plot.

the presence of $200 \mu \mathrm{g} / \mathrm{mL}$ of synthetic lipids. However, in the case of Lipofectamine ${ }^{\mathrm{TM}} 2000$, more than $50 \%$ cells did not survive at a concentration of $40 \mu \mathrm{g} / \mathrm{mL}$.

\section{Discussion}

Previous studies on neuronal cells with commercially available cationic lipid formulations have shown low transfection efficiency. ${ }^{5}$ Herein, we have reported the preparation of cationic liposomes from the arginine head group with different counterions and a 3-hydrocarbon chain spacer containing synthetic lipids without using any helper lipids, ${ }^{16}$ characterization of the lipoplexes in the presence of serum, and investigation of the lipoplex morphology. We have also demonstrated that arginine-based cationic lipids are the most efficient gene delivery vehicles to neuronal cells and HeLa cells when compared with lysine-based cationic assemblies and Lipofectamine 2000.

Recently, we reported that the size, zeta potential, phase transition temperature, and morphology of lysine-based cationic assemblies were influenced by the ionization states of the lysine head group and the length of the hydrocarbon chain spacer. ${ }^{38}$ For example, $\mathbf{c}$ formed a micellar structure and there was no phase transition temperature determined for $\mathbf{c}$. In contrast, $\mathbf{d}$ formed a multi-lamellar vesicular structure and the phase transition temperature was $24.5^{\circ} \mathrm{C}$. The size and the zeta potential of cationic liposomes $\mathbf{a}$ and $\mathbf{b}$ in the present study were influenced by the arginine head group ionization states (Table 1). However, the phase transition temperature remained almost the same and the morphology of the cationic liposomes was vesicular (Figure 2A-B). We speculate that this discrepancy of the influence of ionization states is due to the guanidino group of arginine. The higher zeta potential $(+45 \mathrm{mV})$ of $\mathbf{b}$ is due to the higher tendency of the TFA counterion to be protonated in comparison to its
$\mathrm{HCl}$ counterpart. ${ }^{38}$ The lipoplexes prepared from $\mathbf{a}$ and $\mathbf{b}$ coalesced into solid spheres unlike the vesicular liposomes (Figures 2A-D and 3A-D). More specifically, the mixing of pDNA with cationic liposomes induces liposome aggregation and lamellar condensation. In this case, the pDNA acted as a bridge among the cationic membranes and also stabilized the condensed lamellar phase. It has also been proposed that the condensed lamellar structures are composed of alternating layers of cationic lipid bilayers and pDNA. ${ }^{39}$

The physicochemical properties (ie, size and zeta potential) of lipoplexes strongly influence their gene delivery efficiency. ${ }^{40-42}$ It has been reported that lipoplexes with larger particle size show elevated transfection efficiency because of their maximum contact with the cells, and larger particles taken up by cells lead to the formation of large intracellular vesicles that are more easily disrupted, thus releasing DNA into the cytoplasm. ${ }^{43}$ Our data also indicate that larger lipoplex particles formed when prepared in the absence of serum than when in the presence of serum and thus elevated transfection efficiency in the absence of serum. For example, in the absence of serum, the size and zeta potential of the lipoplexes exhibiting the highest transfection efficiency in both the cell lines were $652 \mathrm{~nm}$ and $+23 \mathrm{mV}$, respectively, for a at a $15 / 1(\mathrm{w} / \mathrm{w})$ ratio and $661 \mathrm{~nm}$ and $+14 \mathrm{mV}$, respectively, for $\mathbf{b}$ at a 10/1 ratio. However, in the presence of serum, the size and zeta potential of the lipoplexes exhibiting the highest transfection efficiency in both the cell lines were $217 \mathrm{~nm}$ and $-11 \mathrm{mV}$, respectively, for a at a $15 / 1 \mathrm{w} / \mathrm{w}$ or $6.4 \mathrm{~N} / \mathrm{P}$ ratio and $270 \mathrm{~nm}$ and $-10 \mathrm{mV}$, respectively, for $\mathbf{b}$ at a $10 / 1$ w/w or $4.26 \mathrm{~N} / \mathrm{P}$ ratio. In contrast, Kreiss et al reported that lipoplex morphologies were determined by the competitive interactions between electrostatic forces and elasticity forces driven by the lipid hydrophobic moiety. ${ }^{44}$ Therefore, $\mathbf{a} / \mathrm{pDNA}$ and $\mathbf{b} / \mathrm{pDNA}$ lipoplexes images showed spherical 
and lamellar structures. It has been demonstrated that the lamellar structure of the lipoplexes could be present during the condensation and transport of the DNA but a more aggressive inverted hexagonal structure would form on contact with the cell membrane. ${ }^{43}$

It has been reported that pDNA is rarely released from cationic complexes because of the strong electrostatic interaction between the cationic carrier and the anionic heparan sulfate. ${ }^{45}$ Similarly, in our study, we demonstrated that the negative zeta potential of the lipoplexes is due to the adsorption of the negatively charged serum proteins on the positively charged lipoplexes, which maintains the ionization equilibrium, rather than because of the exchange of pDNA with anionic serum proteins. Further, the reduced size of the lipoplexes in the presence of serum is due to the increased electrostatic repulsion among the negatively charged lipoplexes (Figure S3). This phenomenon is also supported by gel retardation assay in the presence of 10\% FBS (Figure 5). When the surface charge of the lipoplexes is positive, there will be electrostatic interaction with the negatively charged cell membrane. However, the interaction between the negatively charged lipoplexes and the cell membrane is unclear. We speculate that the cellular uptake mechanism of the lipoplexes prepared in the absence and in the presence of serum might be different. Further studies are underway to investigate the cellular uptake mechanism of the lipoplexes prepared both in the presence and in the absence of serum. Moreover, the lipoplexes formed at a higher lipid-to-pDNA ratio (ie, $\geq 15 / 1 \mathrm{w} / \mathrm{w}$ or $\geq 6.4 \mathrm{~N} / \mathrm{P}$ ) showed a lower transfection efficiency due to higher $\mathrm{N} / \mathrm{P}$ ratios.

The gene delivery efficiency of a in PC-12 cells was found to be significantly higher than that of $\mathbf{b}-\mathbf{d}$ (Figure 6A) at a ratio of $15 / 1 \mathrm{w} / \mathrm{w}$ in the absence of serum. That $\mathbf{a}$ at a ratio of $15 / 1 \mathrm{w} / \mathrm{w}$ has the highest efficiency is due to the elevated zeta potential (ie, $+23 \mathrm{mV}$ ) of the lipoplex, which results in a stronger interaction with the cell membrane and, in turn, increased cellular uptake. An excess amount of lipid was required to either form a protective shield or provide the extra positive charge required to interact with the cell membrane. ${ }^{10}$

However, in HeLa cells, b showed the highest gene delivery efficiency at a ratio of $10 / 1 \mathrm{w} / \mathrm{w}$ when compared with a and $\mathbf{c}-\mathbf{d}$ in the absence of serum (Figure 6B). The superior efficiency of $\mathbf{b}$ can be explained in terms of the counterions present in the cationic head group and the type of cationic amino acid. Recently, we reported that cationic assemblies with TFA-salt show the highest gene delivery efficiency in comparison with their $\mathrm{HCl}$-salt and $-\mathrm{NH}_{2}$ form counter- parts in the COS-7 cell line. ${ }^{38}$ Further, the guanidino group increases the ability of cationic liposomes with an arginine head group to condense negatively charged DNA. The $p K_{a}$ values of the guanidino group and the amino group of arginine are 12.48 and 9.04, respectively. Therefore, the arginine head group that remains bi-cationic at physiological $\mathrm{pH}$ (ie, $\mathrm{pH}$ 7.4) and lower pHs, forms zwitterionic hydrogen bonds with phosphate ions, which are capable of forming hydrogen bonds with nucleic acid bases, and plays a vital role in DNA binding proteins such as histones and protamines. ${ }^{24,46}$

Moreover, hydrogen bond formation of the guanidino moiety in arginine with phosphates, sulfates, and carboxylates on the cell membrane components might be influenced synergistically. ${ }^{47}$ Previous studies have shown that biodegradable arginine-based poly(ester-amide) ${ }^{18}$ and argininerich peptides such as HIV-1 Tat peptide and antennapedia homeodomain have been used as gene delivery vehicles since the former can deliver DNA to nearly $100 \%$ of cells and the latter can easily translocate through cell membranes. ${ }^{17}$ In the presence of serum, the gene delivery efficiency of a was the highest in PC-12 cells (Figure 6C and B) showed the highest gene delivery efficiency in HeLa cells (Figure 6D). The efficiency was lower in the presence than in the absence of serum. The reduced efficiency in the presence of serum was due to the negative zeta potential of the lipoplexes at all lipidto-pDNA ratios (Figure 4B and D), which reduced cellular uptake. The surface charges significantly affect the cellular uptake, with positive charges promoting and increasing internalization via electrostatic interaction. ${ }^{48}$ Our data demonstrate that the transfection efficiency of $\mathbf{a}$ in PC-12 cells was 4- and 4.5-fold greater than that of Lipofectamine ${ }^{\mathrm{TM}}$ 2000 in the absence and presence of serum, respectively. Similarly, the transfection efficiency of $\mathbf{b}$ in HeLa cells was 1.5- and 1.8-fold greater than that of Lipofectamine ${ }^{\mathrm{TM}}$ 2000 in the absence and presence of serum, respectively. Further, $\mathbf{b}$ also showed the highest transfection efficiency in SHSY-5Y cells, which was 6- and 3-fold greater than that of Lipofectamine ${ }^{\mathrm{TM}} 2000$ in the absence and in the presence of serum, respectively (data not shown).

The transfection efficiency of the cationic assemblies differs from cell line to cell line and may be due to the different cellular uptake efficiency of the lipoplexes. Because of the difference in the cell membrane properties ${ }^{49}$ and surface charge, each cell would undergo a different degree of electrostatic interaction with the lipoplexes prepared from the different cationic assemblies and this could affect cell uptake efficiency. ${ }^{10,50}$ Different cell membrane glycosaminoglycan (GAG) and proteoglycan compositions can also influence 
the interaction of the cell membranes with the lipoplexes. ${ }^{51}$ Moreover, the cell doubling time differs from cell line to cell line, which influences the entry of pDNA into the nucleus. ${ }^{52}$ The ammonium groups in lysine form monodentate hydrogen bonding with the cell membrane components, whereas bidentate hydrogen bonding occurs for a guanidino group in arginine. ${ }^{53}$ Further, the cell uptake mechanism of a lysine head group containing polyplexes involves a GAG-dependent endocytic route, whereas their arginine counterparts utilize GAG-independent endocytosis. ${ }^{53}$ Therefore, in our study, the lysine head group containing cationic assemblies showed lower transfection efficiency than their arginine head group counterparts.

The cytotoxicity of the arginine-based cationic liposomes was investigated in neuronal and HeLa cells (Figure 7A and B) and compared with that of Lipofectamine ${ }^{\mathrm{TM}} 2000$. Both the cationic liposomes showed very low cytotoxicity to SHSY-5Y (data not shown), PC-12, and HeLa cells in the presence of serum. The low cytotoxicity of the argininebased cationic liposomes can be attributed to the presence of ester bonds and amino acid analogs as well as rapid biodegradability post-transfection. The absence of multivalent cationic lipids such as DOTAP, N-[1-(2,3-Dioleoyloxy) propyl]-N,N,N-trimethylammonium methyl-sulfate; DOSPA, 2,3-dioleoyloxy-N-[2-(spermine-carboxamido)ethyl]-N,Ndimethyl-1 propanaminium trifluoroacetate; and DOGS, Di-octadecyl-amido-glycyl-spermine, as well as the absence of any helper lipids such as DOPE, is another important advantage of amino acid-based cationic lipids. This is because multivalent cationic lipids form aggregates with cellular organelles after releasing pDNA, which leads to cellular death. ${ }^{30}$ Further, DOPE increases toxicity to various immune effector cells. ${ }^{54}$

\section{Conclusion}

Different counterions in the arginine head group do not influence the morphology of the cationic liposomes and lipoplexes prepared from arginine-based cationic liposomes. Transfection efficiency of amino acid-based cationic assemblies is influenced by the amino acids (ie, arginine or lysine) present in the hydrophilic head group as well as their ionization states. More specifically, arginine-based cationic liposomes are better than lysine-based cationic assemblies in terms of gene delivery efficiency regardless of the presence of serum or ionization state. The transfection efficiency of amino acid-based cationic assemblies is greater than that of the commercially available Lipofectamine ${ }^{\mathrm{TM}} 2000$ and varies from the cell line to cell line. The cytotoxicity is also comparatively very low. Therefore, arginine-based cationic liposomes are a potential candidate for in vitro delivery of genetic materials to different cell lines as well as primary neuronal cultures.

\section{Acknowledgments}

This work was partially supported by the Global Center of Practical Chemical Wisdom and High Tech Research Center project of Waseda University. The Waseda University project funding was matched by a fund subsidy from the Ministry of Education, Culture, Sports, Science and Technology - Japan.

\section{Disclosure}

The authors declare no conflicts of interest in this work.

\section{References}

1. Felgner PL, Gadek TR, Holm M, et al. Lipofection: a highly efficient, lipid-mediated DNA-transfection procedure. Proc Natl Acad Sci USA. 1987;84(21):7413-7417.

2. Bergen JM, Park IK, Horner PJ, Pun SH. Nonviral approaches for neuronal delivery of nucleic acids. Pharm Res. 2008;25(5):983-998.

3. Anderson WF. Human gene therapy. Nature. 1998;392(Suppl 6679): 25-30.

4. Bharali DJ, Klejbor I, Stachowiak EK, et al. Organically modified silica nanoparticles: a nonviral vector for in vivo gene delivery and expression in the brain. Proc Natl Acad Sci U S A. 2005;102(32):11539-11544.

5. Corso TD, Torres G, Goulah C, et al. Transfection of tyrosine kinase deleted FGF receptor-1 into rat brain substantia nigra reduces the number of tyrosine hydroxylase expressing neurons and decreases concentration levels of striatal dopamine. Brain Res Mol Brain Res. 2005;139(2):361-366.

6. Xu Z, Yue Y, Lai Y, et al. Trans-splicing adeno-associated viral vectormediated gene therapy is limited by the accumulation of spliced mRNA but not by dual vector coinfection efficiency. Human Gene Ther. 2004;15(9):896-905.

7. Boyce N. Trial halted after gene shows up in semen. Nature. 2001; 414(6865):677.

8. Davis SS. Biomedical applications of nanotechnology - implications for drug targeting and gene therapy. Trends Biotechnol. 1997;15(6): 217-224.

9. Li S, Tseng WC, Stolz DB, Wu SP, Watkins SC, Huang L. Dynamic changes in the characteristics of cationic lipidic vectors after exposure to mouse serum: implications for intravenous lipofection. Gene Ther. 1999;6(4):585-594.

10. Obata Y, Ciofani G, Raffa V, et al. Evaluation of cationic liposomes composed of an amino acid-based lipid for neuronal transfection. Nanomedicine. 2010;6(1):70-77.

11. Shi N, Pardridge WM. Noninvasive gene targeting to the brain. Proc Natl Acad Sci U S A. 2000;97(13):7567-7572.

12. Abdallah B, Hassan A, Benoist C, Goula D, Behr JP, Demeneix BA. A powerful nonviral vector for in vivo gene transfer into the adult mammalian brain: polyethylenimine. Human Gene Ther. 1996;7(16): 1947-1954.

13. Barati S, Chegini F, Hurtado P, Rush RA. Hybrid tetanus toxin C fragment-diphtheria toxin translocation domain allows specific gene transfer into PC12 cells. Exp Neurol. 2002;177(1):75-87.

14. Usachev YM, Khammanivong A, Campbell C, Thayer SA. Particlemediated gene transfer to rat neurons in primary culture. Pflugers Arch. 2000;439(6):730-738. 
15. Xiang JJ, Tang JQ, Zhu SG, et al. IONP-PLL: a novel non-viral vector for efficient gene delivery. J Gene Med. 2003;5(9):803-817.

16. Adami RC, Seth S, Harvie P, et al. An amino acid-based amphoteric liposomal delivery system for systemic administration of siRNA. Mol Ther. 2011;19(6):1141-1151.

17. Futaki S, Ohashi W, Suzuki T, et al. Stearylated arginine-rich peptides: a new class of transfection systems. Bioconjug Chem. 2001;12(6): 1005-1011.

18. Yamanouchi D, Wu J, Lazar AN, Kent KC, Chu CC, Liu B. Biodegradable arginine-based poly(ester-amide)s as non-viral gene delivery reagents. Biomaterials. 2008;29(22):3269-3277.

19. Prata CA, Zhang XX, Luo D, McIntosh TJ, Barthelemy P, Grinstaff MW. Lipophilic peptides for gene delivery. Bioconjug Chem. 2008;19(2): 418-420.

20. Karmali PP, Kumar VV, Chaudhuri A. Design, syntheses and in vitro gene delivery efficacies of novel mono-, di- and trilysinated cationic lipids: a structure-activity investigation. J Med Chem. 2004;47(8): 2123-2132.

21. Gärtner A, Collin L, Lalli G. Nucleofection of primary neurons. Meth Enzymol. 2006;406:374-388.

22. Leclere PG, Panjwani A, Docherty R, Berry M, Pizzey J, Tonge DA. Effective gene delivery to adult neurons by a modified form of electroporation. J Neurosci Methods. 2005;142(1):137-143.

23. Behr JP, Demeneix B, Loeffler JP, Perez-Mutul J. Efficient gene transfer into mammalian primary endocrine cells with lipopolyamine-coated DNA. Proc Natl Acad Sci U SA. 1989;86(18):6982-6986.

24. Sen J, Chaudhuri A. Design, syntheses, and transfection biology of novel non-cholesterol-based guanidinylated cationic lipids. J Med Chem. 2005;48(3):812-820.

25. Choi JS, Lee EJ, Jang HS, Park JS. New cationic liposomes for gene transfer into mammalian cells with high efficiency and low toxicity. Bioconjug Chem. 2001;12(1):108-113.

26. Bajaj A, Paul B, Indi SS, Kondaiah P, Bhattacharya S. Effect of the hydrocarbon chain and polymethylene spacer lengths on gene transfection efficacies of gemini lipids based on aromatic backbone. Bioconjug Chem. 2007;18(6):2144-2158.

27. Kim WJ, Christensen LV, Jo S, et al. Cholesteryl oligoarginine delivering vascular endothelial growth factor siRNA effectively inhibits tumor growth in colon adenocarcinoma. Mol Ther. 2006;14(3):343-350.

28. Felgner JH, Kumar R, Sridhar CN, et al. Enhanced gene delivery and mechanism studies with a novel series of cationic lipid formulations. J Biol Chem. 1994;269(4):2550-2561.

29. Wasungu L, Hoekstra D. Cationic lipids, lipoplexes and intracellular delivery of genes. J Control Release. 2006;116(2):255-264.

30. Obata Y, Suzuki D, Takeoka S. Evaluation of cationic assemblies constructed with amino acid based lipids for plasmid DNA delivery. Bioconjug Chem. 2008;19(5):1055-1063.

31. Ghosh YK, Visweswariah SS, Bhattacharya S. Advantage of the ether linkage between the positive charge and the cholesteryl skeleton in cholesterol-based amphiphiles as vectors for gene delivery. Bioconjug Chem. 2002;13(2):378-384.

32. Rajesh M, Sen J, Srujan M, Mukherjee K, Sreedhar B, Chaudhuri A. Dramatic influence of the orientation of linker between hydrophilic and hydrophobic lipid moiety in liposomal gene delivery. $\mathrm{JAm}$ Chem Soc. 2007;129(37):11408-11420.

33. Gopal V, Prasad TK, Rao NM, Takafuji M, Rahman MM, Ihara H. Synthesis and in vitro evaluation of glutamide-containing cationic lipids for gene delivery. Bioconjug Chem. 2006;17(6):1530-1536.

34. Bajaj A, Kondiah P, Bhattacharya S. Design, synthesis, and in vitro gene delivery efficacies of novel cholesterol-based gemini cationic lipids and their serum compatibility: a structure-activity investigation. J Med Chem. 2007;50(10):2432-2442.

35. Bajaj A, Kondaiah P, Bhattacharya S. Effect of the nature of the spacer on gene transfer efficacies of novel thiocholesterol derived gemini lipids in different cell lines: a structure-activity investigation. J Med Chem. 2008;51(8):2533-2540.
36. Obata Y, Saito S, Takeda N, Takeoka S. Plasmid DNA-encapsulating liposomes: effect of a spacer between the cationic head group and hydrophobic moieties of the lipids on gene expression efficiency. Biochim Biophys Acta. 2009;1788(5):1148-1158.

37. Zhang XX, Prata CA, McIntosh TJ, Barthélémy P, Grinstaff MW. The effect of charge-reversal amphiphile spacer composition on DNA and siRNA delivery. Bioconjug Chem. 2010;21(5):988-993.

38. Sarker SR, Arai S, Murate M, et al. Evaluation of the influence of ionization states and spacers in the thermotropic phase behaviour of amino acid-based cationic lipids and the transfection efficiency of their assemblies. Int J Pharm. 2012;422(1-2):364-373.

39. Weisman S, Hirsch-Lerner D, Barenholz Y, Talmon Y. Nanostructure of cationic lipid-oligonucleotide complexes. Biophys J. 2004;87(1): 609-614.

40. Cardoso AM, Faneca H, Almeida JA, et al. Gemini surfactant dimethylene-1,2-bis(tetradecyldimethylammonium bromide)-based gene vectors: a biophysical approach to transfection efficiency. Biochim Biophys Acta. 2011;1808(1):341-351.

41. Rao NM, Gopal V. Cell biological and biophysical aspects of lipidmediated gene delivery. Biosci Rep. 2006;26(4):301-324.

42. Almofti MR, Harashima H, Shinohara Y, Almofti A, Li W, Kiwada H. Lipoplex size determines lipofection efficiency with or without serum. Mol Membr Biol. 2003;20(1):35-43.

43. Ma B, Zhang S, Jiang H, Zhao B, Lv H. Lipoplex morphologies and their influences on transfection efficiency in gene delivery. $J$ Control Release. 2007;123(3):184-194.

44. Kreiss P, Cameron B, Rangara R, et al. Plasmid DNA size does not affect the physicochemical properties of lipoplexes but modulates gene transfer efficiency. Nucleic Acids Res. 1999;27(19):3792-3798.

45. Ruponen M, Ylä-Herttuala S, Urtti A. Interactions of polymeric and liposomal gene delivery systems with extracellular glycosaminoglycans: physicochemical and transfection studies. Biochim Biophys Acta. 1999;1415(2):331-341.

46. Vigneron JP, Oudrhiri N, Fauquet M, et al. Guanidinium-cholesterol cationic lipids: efficient vectors for the transfection of eukaryotic cells. Proc Natl Acad Sci U S A. 1996;93(18):9682-9686.

47. Nakase I, Takeuchi T, Tanaka G, Futaki S. Methodological and cellular aspects that govern the internalization mechanisms of arginine-rich cellpenetrating peptides. Adv Drug Deliv Rev. 2008;60(4-5):598-607.

48. Yue ZG, Wei W, Lv PP, et al. Surface charge affects cellular uptake and intracellular trafficking of chitosan-based nanoparticles. Biomacromolecules. 2011;12(7):2440-2446.

49. Callaghan R, van Gorkom LC, Epand RM. A comparison of membrane properties and composition between cell lines selected and transfected for multi-drug resistance. Br J Cancer. 1992;66(5):781-786.

50. Chakravarthy BR, Spence MW, Clarke JT, Cook HW. Rapid isolation of neuroblastoma plasma membranes on Percoll gradients. Characterization and lipid composition. Biochim Biophys Acta. 1985;812(1):223-233.

51. Ruponen M, Honkakoski P, Tammi M, Urtti A. Cell-surface glycosaminoglycans inhibit cation-mediated gene transfer. J Gene Med. 2004;6(4):405-414.

52. Zuhorn IS, Hoekstra D. On the mechanism of cationic amphiphilemediated transfection. To fuse or not to fuse: is that the question? J Membr Biol. 2002;189(3):167-179.

53. Naik RJ, Chandra P, Mann A, Ganguli M. Exogenous and cell surface glycosaminoglycans alter DNA delivery efficiency of arginine and lysine homopeptides in distinctly different ways. J Biol Chem. 2011; 286(21):18982-18993.

54. Filion MC, Phillips NC. Toxicity and immunomodulatory activity of liposomal vectors formulated with cationic lipids toward immune effector cells. Biochim Biophys Acta. 1997;1329(2):345-356. 


\section{Supplementary information}

\section{Synthetic procedures}

Syntheses of cationic lipids $\mathbf{a}$ and $\mathbf{b}$

Step I

First, 4-Amino butyric acid ( $5 \mathrm{~g}, 48.5 \mathrm{mmol})$ was dissolved in $100 \mathrm{~mL}$ dioxane/distilled $\mathrm{H}_{2} \mathrm{O}(2: 1)$ solution then 1.2 equivalent $\mathrm{NaOH}(58.2 \mathrm{mmol})$ and 1.2 equivalent di-tert-butyl dicarbonate were added. After stirring for 12 hours at room temperature, the solvent was evaporated and ethyl acetate $(100 \mathrm{~mL})$ was added to the viscous liquid. The ethyl acetate solution was treated with a $0.2 \mathrm{~N}$ hydrochloride solution $(200 \mathrm{~mL} \times 2)$ and washed with distilled water $(200 \mathrm{~mL} \times 2)$. After the solution was evaporated, $N$-butoxycarbonylaminobutyric acid was recrystallized from hexane $(100 \mathrm{~mL})$ at $4{ }^{\circ} \mathrm{C}$ to obtain a white powder ( $91 \%$ yield).

\section{Step 2}

$\mathrm{N}$-Butoxycarbonyl-aminobutyric acid (1.96 g, $9.67 \mathrm{mmol})$ was dissolved in dichloromethane $(20 \mathrm{~mL})$ and this was followed by the addition of BOP $(5.12 \mathrm{~g}, 11.60 \mathrm{mmol})$. Then, 1,5-ditetradecyl-L-glutamate $(4.74 \mathrm{~g}, 8.79 \mathrm{mmol})$ and triethylamine $(1.45 \mathrm{~mL}, 10.54 \mathrm{mmol})$ were added to the solution. After stirring for 12 hours at room temperature, the solution was treated with a saturated sodium carbonate solution $(200 \mathrm{~mL} \times 2)$ and washed with distilled water $(200 \mathrm{~mL} \times 2)$. After the solution was evaporated, 1,5ditetradecyl- $N$-butoxycarbonyl- $N$-trityl-L-glutamate was recrystallized from methanol at $4^{\circ} \mathrm{C}$ to obtain a white powder (95\% yield). The powder was dissolved in dichloromethane $(4 \mathrm{~mL})$ then trifluoroacetic acid $(10 \mathrm{~mL})$ was added to the solution to remove the Boc group. After incubation overnight at $4^{\circ} \mathrm{C}$, the solution was treated with a saturated sodium carbonate solution $(200 \mathrm{~mL} \times 2)$ and washed with distilled water $(200 \mathrm{~mL} \times 2)$. Finally, 1, 5-ditetradecyl- $N$-trityl-Lglutamate was obtained as a white powder ( $82 \%$ yield) after evaporating the solution.

\section{Step 3}

The intermediate obtained at Step 2 (2 g, $3.20 \mathrm{mmol})$ was dissolved in dichloromethane $(10 \mathrm{~mL})$. Then triethylamine (3.84 mmol), Boc-Arg(Boc) $)_{2}-\mathrm{OH}(1.5 \mathrm{~g}, 3.16 \mathrm{mmol})$, and benzotriazol-1-yloxytris (dimethylamino) phosphonium hexafluorophosphate (BOP) $(1.67 \mathrm{~g}, 3.79 \mathrm{mmol})$ were added to the solution. Following stirring for 12 hours at room temperature, the solution was treated with a saturated sodium carbonate solution $(200 \mathrm{~mL} \times 2)$ and washed with distilled water $(200 \mathrm{~mL} \times 2)$. After the solution was evaporated, 1,5-ditetradecyl- $N$-butoxycarbonyl- $N$-trityl- $N$-arginyl-L- glutamate was purified by column chromatography using 60-120 mesh size silica gel. The solvent used to perform column chromatography was hexane:ethyl acetate (3/1 ratio) (48\% yield).

In the case of cationic lipid a, 1,5-ditetradecyl$N$-butoxycarbonyl- $N$-arginyl- $N$-trityl-L-glutamate $(260 \mathrm{mg}$ ) was deprotected with $\mathrm{HCl}(4 \mathrm{M})$ in ethyl acetate at $4^{\circ} \mathrm{C}$ for 12 hours and the excess $\mathrm{HCl}$ was removed under reduced pressure followed by flushing with nitrogen to give the title compound as a chloride salt ( $95 \%$ yield). In the case of cationic lipid b, 1,5-ditetradecyl- $N$-butoxycarbonyl- $N$-arginyl- $N$-tritylL-glutamate $(110 \mathrm{mg})$ was dissolved in dichloromethane $(2 \mathrm{~mL})$ followed by the addition of TFA $(10 \mathrm{~mL})$. The resulting solution was left stirring at room temperature overnight. Excess TFA was removed under reduced pressure followed by flushing with nitrogen to give the title compound as a TFA salt ( $96 \%$ yield). Both cationic lipids a and b were characterized by ${ }^{1} \mathrm{H}-\mathrm{NMR},{ }^{13} \mathrm{C}-\mathrm{NMR}$ (Varian-Oxford AS400 nuclear magnetic resonance [NMR] spectrometer [400 MHz]; Palo Alto, CA, USA) spectroscopy and ESI-MS (Thermo Fisher Scientific, LCQ Fleet (USA)).

\section{NMR and ESI-MS data}

\section{I, 5-ditetradecyl- $N$-arginyl- $N$-trityl-L-glutamate}

$\mathrm{NH}_{3}{ }^{+} \mathrm{Cl}^{-}$salt form (deprotected with $\mathrm{HCl}(4 \mathrm{M}$ )

and non-neutralized)

Cationic lipid a: $\mathrm{R}_{\mathrm{f}} 0.2\left(\mathrm{CHCl}_{3}: \mathrm{MeOH} 4: 1\right) .{ }^{1} \mathrm{H}-\mathrm{NMR}$ $\left(\mathrm{CDCl}_{3}: \mathrm{MeOD} 10: 1,400 \mathrm{MHz}, \delta \mathrm{ppm}\right): 0.88\left(\mathrm{t}, 6 \mathrm{H}_{2} \mathrm{CH}_{2} \mathrm{CH}_{3}\right.$ ); 1.20-1.30 (br, $46 \mathrm{H}, \mathrm{CH}_{2 \text { (myristoyl) }}, \mathrm{CONHCH}_{2} \mathrm{CH}_{2}$ ); 1.58-1.67 (m, $\left.4 \mathrm{H}, \mathrm{COOCH}_{2} \mathrm{CH}_{2}\right) ; 1.69-1.88\left(\mathrm{~m}, 4 \mathrm{H}, \mathrm{NH}_{2} \mathrm{CHCH}_{2}\right.$, $\left.\mathrm{NH}_{2} \mathrm{CHCH}_{2} \mathrm{CH}_{2}\right) ; 1.98-2.19\left(\mathrm{~m}, 4 \mathrm{H}, \mathrm{CONHCHCH}{ }_{2}\right.$, $\mathrm{CONHCH}_{2} \mathrm{CH}_{2} \mathrm{CH}_{2}$ ); 2.33-2.36 (t, $2 \mathrm{H}, \mathrm{CONHCHCH}_{2} \mathrm{CH}_{2}$ ); 2.42-2.46 (m, 2H, $\left.\mathrm{NH}_{2} \mathrm{CHCH}_{2} \mathrm{CH}_{2} \mathrm{CH}_{2}\right) ; 3.37-3.39$ (m, $\left.2 \mathrm{H}, \mathrm{CONHCH}_{2}\right) ; 4.04-4.15$ (m, $5 \mathrm{H}, \mathrm{COOCH}_{2}, \mathrm{NH}_{2} \mathrm{CH}$ ); 4.44-4.47 (q, 1H, NHCH). ${ }^{13} \mathrm{C}-\mathrm{NMR}\left(\mathrm{CDCl}_{3}: \mathrm{MeOD} 10: 1\right.$, $400 \mathrm{MHz}, \delta \mathrm{ppm}): 52.03,52.91,65.22,65.97,168.85$, 172.62, 173.26, 174.00. MS (ESI): $(\mathrm{M}+\mathrm{H})^{+}$calculated for $\mathrm{C}_{43} \mathrm{H}_{84} \mathrm{~N}_{4} \mathrm{O}_{6}, 780.65$; found, 780.55 .

$\mathrm{NH}_{3}{ }^{+}$TFA $^{-}$salt form (deprotected with TFA and non-neutralized)

Cationic lipid b: $\mathrm{R}_{\mathrm{f}} 0.2\left(\mathrm{CHCl}_{3}: \mathrm{MeOH} 4: 1\right)$. ${ }^{1} \mathrm{H}-\mathrm{NMR}$ $\left(\mathrm{CDCl}_{3}: \mathrm{MeOD} 10: 1,400 \mathrm{MHz}, \delta \mathrm{ppm}\right): 0.88\left(\mathrm{t}, 6 \mathrm{H}, \mathrm{CH}_{2} \mathrm{CH}_{3}\right)$; $1.21-1.30$ (br, $46 \mathrm{H}, \mathrm{CH}_{2 \text { (myristoyl) }}, \mathrm{CONHCH}_{2} \mathrm{CH}_{2}$ ); $1.58-1.65\left(\mathrm{~m}, 4 \mathrm{H}, \mathrm{COOCH}_{2} \mathrm{CH}_{2}\right) ; 1.76-2.19(\mathrm{~m}$, $6 \mathrm{H}, \mathrm{NH}_{2} \mathrm{CHCH}_{2}, \mathrm{NH}_{2} \mathrm{CHCH}_{2} \mathrm{CH}_{2}, \mathrm{CONHCHCH}_{2}$ ); 2.24-2.28 (t, $\left.2 \mathrm{H}, \mathrm{CONHCH}_{2} \mathrm{CH}_{2} \mathrm{CH}_{2}\right) ; 2.39-2.43(\mathrm{~m}, 2 \mathrm{H}$, $\left.\mathrm{CONHCHCH}_{2} \mathrm{CH}_{2}\right) ; 3.19-3.23\left(\mathrm{~m}, 2 \mathrm{H}, \mathrm{CONHCH}_{2}\right)$; 
3.25-3.30 (m, 2H, $\left.\mathrm{NH}_{2} \mathrm{CHCH}_{2} \mathrm{CH}_{2} \mathrm{CH}_{2}\right) ; 3.91-3.94(\mathrm{~m}, 1 \mathrm{H}$, $\left.\mathrm{NH}_{2} \mathrm{CH}\right) ; 4.04-4.14\left(\mathrm{~m}, 4 \mathrm{H}, \mathrm{COOCH}_{2}\right) ; 4.44-4.48(\mathrm{q}, 1 \mathrm{H}$, $\mathrm{NHCH}) .{ }^{13} \mathrm{C}-\mathrm{NMR}\left(\mathrm{CDCl}_{3}: \mathrm{MeOD} 10: 1,400 \mathrm{MHz}, \delta \mathrm{ppm}\right)$ : 52.01, 52.95, 65.19, 65.99, 157.14, 172.58, 173.25, 173.95. MS (ESI): $(\mathrm{M}+\mathrm{H})^{+}$calculated for $\mathrm{C}_{43} \mathrm{H}_{84} \mathrm{~N}_{4} \mathrm{O}_{6}, 780.65$; found, 780.47 .

\section{Investigation of the pDNA binding ability of arginine-based cationic liposomes}

The pDNA binding ability of cationic liposomes a and $\mathbf{b}$ was investigated in the presence of $20 \mathrm{mM}$ HEPES buffer $(\mathrm{pH} 7.4)$. The lipoplexes were prepared at different lipid (0.6-6.0 $\mu \mathrm{g})$ to pDNA $(0.2 \mu \mathrm{g})$ ratios (or $3 / 1$ to $30 / 1 \mathrm{w} / \mathrm{w}$ ratios) and incubated at room temperature for 15-20 minutes. The lipoplex solutions were then diluted with $20 \mathrm{mM}$ HEPES buffer ( $\mathrm{pH}$ 7.4) and adjusted to the final volume of $20 \mu \mathrm{L}$. The solutions were mixed with $3.34 \mu \mathrm{L} 6 \mathrm{X}$ loading dye, loaded onto a previously cast $1 \%$ agarose gel, run at $100 \mathrm{~V}$ for 30 minutes, and visualized using the UV Transilluminator gel documentation unit with BioDoc-It Imaging System.

When the lipoplexes were prepared in $20 \mathrm{mM}$ HEPES buffer ( $\mathrm{pH} 7.4$ ), pDNA was efficiently sequestered by both

A



Figure SI Gel retardation assay of the lipoplexes prepared at different lipid $(0.6-6.0 \mu \mathrm{g})$ to plasmid $(\mathrm{p})$ DNA $(0.2 \mu \mathrm{g})$ ratios (or $3 / \mathrm{l}$ to $30 / \mathrm{l} \mathrm{w} / \mathrm{w}$ ratios) and diluted with $20 \mathrm{mM}$ 4-(2-hydroxyethyl)-I-piperazineethanesulfonic acid (HEPES) buffer ( $\mathrm{pH}$ 7.4). (A) $\mathbf{a}$ and (B) b. cationic lipids at a charge ratio of $5 / 1$, whereas a moderate binding ability was appreciable at a charge ratio of $3 / 1$ (Figure S1). There was no visible band at the point of gel loading when the lipid-to-pDNA ratio was greater than 5/1 because the increased amount of cationic lipid shielded the pDNA completely. Further, at the higher lipid/pDNA ratios, the amount of lipid increased but the amount of pDNA remained constant. As a result, the pDNA was bound strongly on the surface of the cationic liposomes. Therefore, no pDNA band was detected at the higher lipid/pDNA ratios.

\section{Investigation of the pDNA binding ability of Lipofectamine ${ }^{\mathrm{TM}} \mathbf{2 0 0 0}$}

The lipoplexes were prepared with pDNA and Lipofectamine ${ }^{\mathrm{TM}} 2000$ at different ratios (w/w) and electrophoresed as described in the methods section.

The pDNA binding ability of Lipofectamine ${ }^{\mathrm{TM}} 2000$ at $1 / 1$ ratio is very poor (Figure $\mathrm{S} 2$, lane 1 ). A moderate pDNA binding ability was observed at $2 / 1$ and $3 / 1$ charge ratios (lanes 2 and 3). Further, Lipofectamine ${ }^{\mathrm{TM}} 2000$ is efficiently complexed with pDNA at charge ratios greater than $4 / 1$, although faint bands are visible at the point of gel loading (lanes 4 to 10).

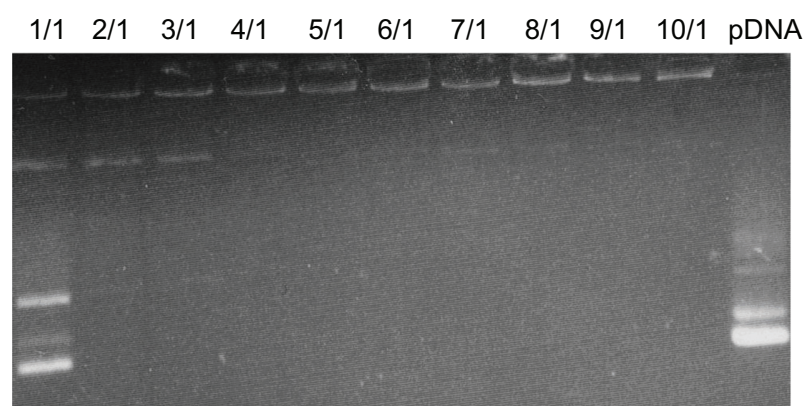

Figure S2 Plasmid (p) DNA binding ability of Lipofectamine ${ }^{\mathrm{TM}} 2000$ at different charge ratios (ie, $1 / \mathrm{I}-10 / \mathrm{l} \mathrm{w} / \mathrm{w}$ ) determined through gel retardation assay. 

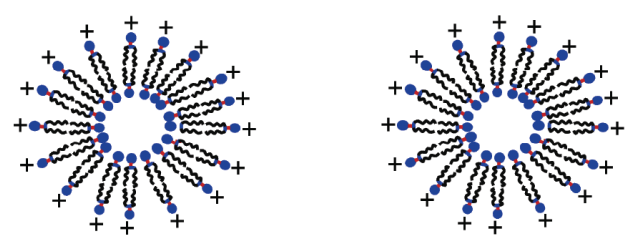

Amino acid-based cationic assemblies

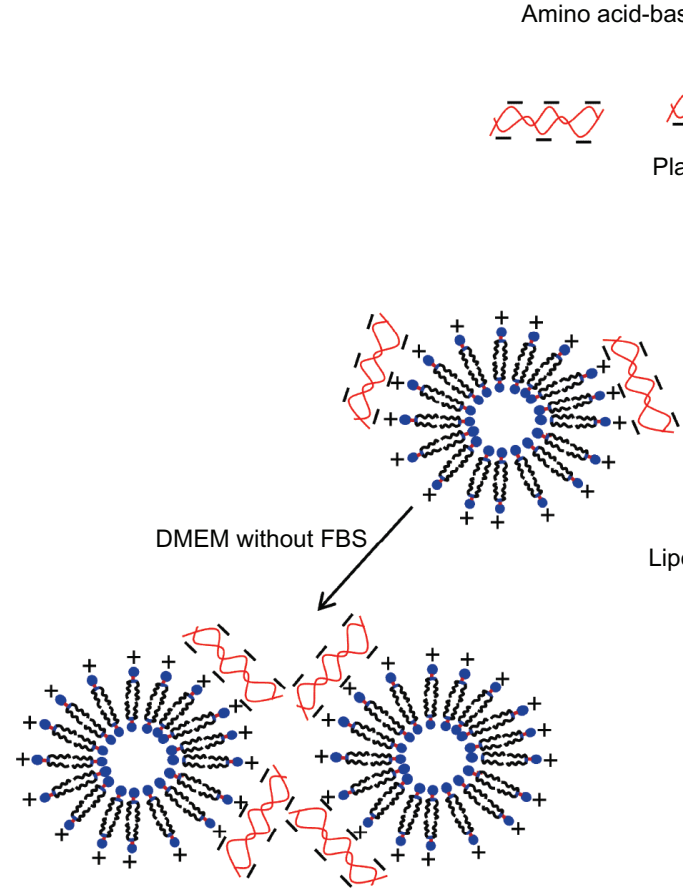

A

- Positive zeta potential

- Large size
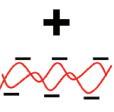

Plasmid DNA

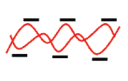

20 mM HEPES (pH 7.4)

$15 \mathrm{~min}$ at room temp
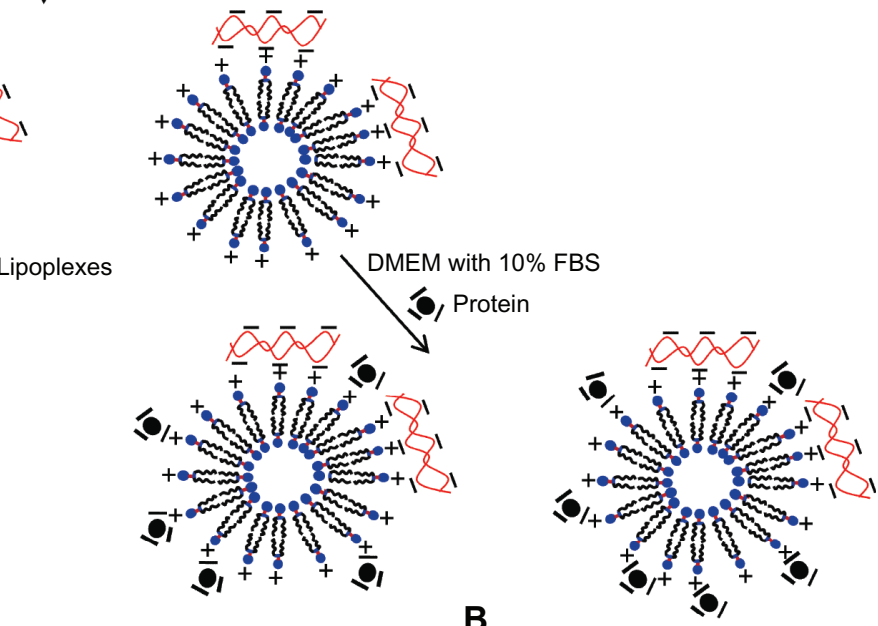

- Negative zeta potential

- Smaller size

Figure S3 Postulated mechanism of the formation of lipoplexes in the absence (A) and presence (B) of serum.

Abbreviations: DMEM, Dulbecco's modified Eagle's medium; FBS, fetal bovine serum; HEPES, 4-(2-hydroxyethyl)-I-piperazineethanesulfonic acid.

\section{Publish your work in this journal}

The International Journal of Nanomedicine is an international, peerreviewed journal focusing on the application of nanotechnology in diagnostics, therapeutics, and drug delivery systems throughou the biomedical field. This journal is indexed on PubMed Central, MedLine, CAS, SciSearch ${ }^{\circledR}$, Current Contents ${ }^{\circledR} /$ Clinical Medicine,
Journal Citation Reports/Science Edition, EMBase, Scopus and the Elsevier Bibliographic databases. The manuscript management system is completely online and includes a very quick and fair peer-review system, which is all easy to use. Visit http://www.dovepress.com/ testimonials.php to read real quotes from published authors. 